\title{
Hypoxic environments as refuge against predatory fish in the Amazonian floodplains
}

\author{
Anjos, MB. ${ }^{\mathrm{a} *}$, De Oliveira, RR. ${ }^{\mathrm{a}}$ and Zuanon, $J .^{\mathrm{b}}$

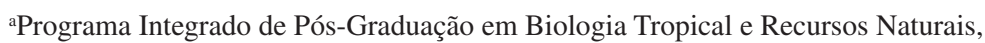 \\ Instituto Nacional de Pesquisas da Amazônia, Universidade Federal do Amazonas - UFAM, \\ Av. André Araújo, 2936, CP 478, CEP 69083-000, Manaus, AM, Brazil

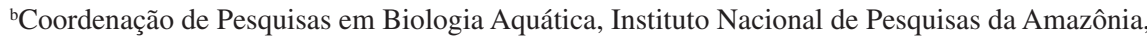 \\ CP 478, CEP 69011-970, Manaus, AM, Brazil \\ *e-mail: maedaangel@ hotmail.com
}

Received February 14, 2006 - Accepted July 17, 2006 - Distributed February 29, 2008

(With 2 figures)

\begin{abstract}
Several groups of Amazonian fishes exhibit behavioral, morphological and physiological characteristics that allow occupying hypoxic environments, despite the energetic costs of living in such harsh conditions. One of the supposed advantages of occupying hypoxic habitats would be a lower predation pressure resulting from a lower number of piscivorous fishes in those environments. We tested this hypothesis in an area of the Amazon River floodplain through gill net fishing in normoxic and hypoxic habitats. From the 103 species caught, 38 were classified as piscivores. We found no difference in the number of piscivorous species captured in hypoxic and normoxic habitats $\left(\chi^{2}=0.23 ; \mathrm{p}=0.63\right.$; $\mathrm{df}=1$ ) but piscivorous individuals were more numerous in normoxic than in hypoxic sampling stations $\left(\chi^{2}=104.4\right.$; $\mathrm{p}<0.001 ; \mathrm{df}=1)$. This indicates that environments submitted to low oxygen conditions may in fact function as refuges against piscivorous fishes in the Amazonian floodplains.
\end{abstract}

Keywords: hypoxia, dissolved oxygen, piscivory, Amazonia.

\section{Ambientes hipóxicos como refúgios contra peixes predadores nas várzeas amazônicas}

\section{Resumo}

Diversos grupos de peixes amazônicos apresentam mecanismos para suportar condições de hipóxia, incluindo especializações comportamentais, morfológicas e fisiológicas, apesar do custo energético envolvido. Uma das supostas vantagens em ocupar ambientes hipóxicos seria a redução da pressão de predação, devido à presença de um menor número de peixes piscívoros. Testamos esta hipótese em um ambiente de várzea do rio Amazonas, por meio de coleta de peixes com malhadeiras em ambientes hipóxicos e normóxicos. Das 103 espécies capturadas, 38 foram classificadas como piscívoras. Não houve diferença no número de espécies piscívoras e não piscívoras nos dois tipos de ambientes amostrados $\left(\chi^{2}=0,23 ; \mathrm{p}=0,63 ; \mathrm{gl}=1\right)$, mas a proporção de peixes piscívoros foi maior sob condições de normóxia $\left(\chi^{2}=104,40 ; \mathrm{p}<0,001 ; \mathrm{gl}=1\right)$. Isto indica que ambientes com baixa concentração de oxigênio dissolvido podem de fato funcionar como locais de refúgio contra peixes piscívoros nas várzeas amazônicas.

Palavras-chave: hipóxia, oxigênio dissolvido, piscivoria, Amazônia.

\section{Introduction}

The Amazon basin covers an area of about $7,000,000 \mathrm{~km}^{2}$ and contains one of the richest freshwater fish faunas of the world (Roberts, 1972; Santos and Ferreira, 1999; Reis et al., 2003). The distribution, composition, and abundance of fish communities in the Amazon are affected by a diverse array of chemical, physical, and biological factors. Among these, the availability of dissolved oxygen has been shown to be a critical determinant of community structure (Kramer et al., 1978; Junk et al., 1983; Saint-Paul and Soares, 1987; Crampton, 1998). In várzea floodplains (lowlands seasonally flooded by turbid water rivers), dissolved oxygen

is subjected to large seasonal variations, as well as daily fluxes (Schmidt, 1973; Junk, 1980; Melack and Fisher, 1983; Furch and Junk, 1997).

Fish inhabiting várzea floodplains have developed diverse morphological, physiological, and behavioral mechanisms to cope with periodically hypoxic conditions that occur, especially during the flooding season (Saint-Paul, 1984; Saint-Paul and Soares, 1987; AlmeidaVal and Hochachka, 1995; Val and Almeida-Val, 1995; Soares and Junk, 2000). However, these mechanisms may represent a costly trade-off to individuals both in terms of energy and time, limiting the energy invested in 
foraging, growth, and reproduction and further contributing to an overall energy deficit. Individuals in hypoxic environments are also more vulnerable to predation, as individuals often obtain oxygen from the water surface, exposing them to both aquatic and aerial predators (Kramer et al., 1983).

The occurrence of adaptations to low oxygen conditions in phylogenetically distant groups and the diversity and abundance of fish inhabiting hypoxic environments indicate adaptive convergence. One of the advantages of being able to inhabit hypoxic environments may be a reduction in predation pressure, since fewer piscivorous fish are supposed to inhabit these areas (Junk et al., 1983). The aim of this study is to assess the spatial distribution of piscivorous fishes in relation to the dissolved oxygen content in central Amazonian floodplain lakes, in order to examine whether predation pressure is lower in hypoxic than in normoxic environments.

\section{Material and Methods}

\subsection{Study area}

The study site is located in Catalão, a floodplain area located approximately $15 \mathrm{~km}$ from Manaus, near the confluence of the Solimões and Negro Rivers ( $3^{\circ} 10^{\prime} 04$ ' S and 59 $54^{\prime} 45^{\prime \prime} \mathrm{W}$ ) (Figure 1). This is a low-lying region with a series of interconnected lakes that, depending on the water level, may become isolated from the surrounding rivers and surrounded by dry várzea forest (Junk, 1980).

The Catalão area is influenced mainly by the white waters of the Solimões River, which has a neutral $\mathrm{pH}$, high electric conductivity and is loaded with suspended solids. Nevertheless, in some years the highly acidic and low conductivity waters from the Negro River may also influence the area (L. F. Alves and A. Darwich, pers. comm.). Dissolved oxygen concentration varies due to local conditions as well as to the hydrologic period. Oxygen concentrations are higher in more open areas

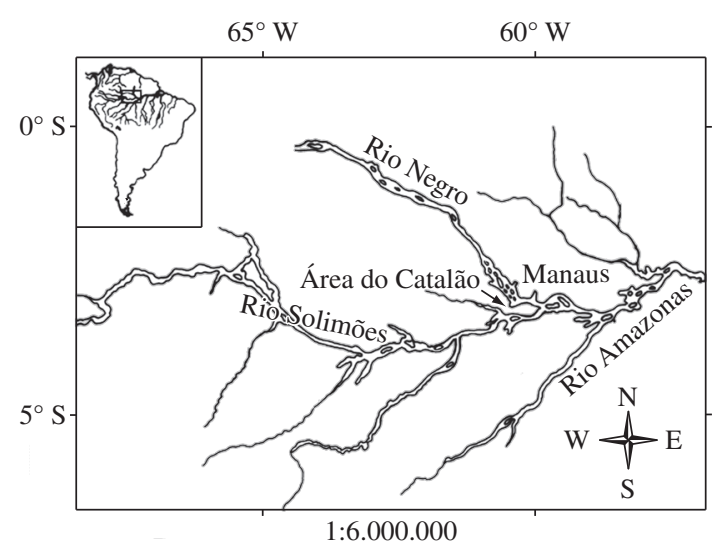

Figure 1. Map of the study site indicating the Catalão area (arrow) at the confluence of the Negro and Solimões Rivers. than inside the flooded forest, and are lower during the flooded than the dry season (Do Vale, 2003; present study).

\section{Methods}

Data were collected in May and June of 2003 and June of 2004, during the high-water season. Ten sampling points were established, five located within flooded forest, in hypoxic conditions (dissolved oxygen concentration $0.20-0.98 \mathrm{mg} . \mathrm{L}^{-1}$; depth $1.45-3.70 \mathrm{~m}$ ) and five located in open water areas, under normoxic conditions (dissolved oxygen concentration 2.34-6.50 mg.L $\mathrm{L}^{-1}$; depth 2.10-5.15 m).

Dissolved oxygen concentration was measured approximately $20 \mathrm{~cm}$ below the surface with an YSI 55 portable digital oxymeter. Fish were captured using sets of five nets with mesh sizes of $30,50,70,90$, and $110 \mathrm{~mm}$, covering an area of $100 \mathrm{~m}^{2}$. The nets were set for 24 hours at each site, and fish were removed every six hours.

The captured individuals were classified to species and then as either piscivorous or non-piscivorous, based on the stomach contents of collected specimens and/or from information available in the literature. Piscivorous fishes were defined as species consuming fish frequently or exclusively (Goulding, 1980; Soares et al., 1986; Ferreira et al., 1998). The Chi-square test (Zar, 1996) was employed to test for differences in the abundance and species richness of piscivorous fishes between the normoxic and hypoxic sampling points.

\section{Results}

A total of 1174 fishes from 22 families, 74 genera, and 103 species was captured. Among the species, 38 were classified as piscivorous; from these, $20(52.6 \%)$ occurred in both normoxic and hypoxic environments, $11(28.9 \%)$ exclusively in normoxic conditions, and seven $(18.4 \%)$ exclusively in hypoxic conditions. At the hypoxic sampling points, 690 fish of 78 species were captured; from these, 73 individuals (10.6\%) and 27 species $(34.6 \%)$ were piscivorous. At the normoxic sampling points, 484 individuals of 81 species were collected; from these, 170 individuals $(35.1 \%)$ were piscivorous, represented by $31(38.3 \%)$ species. A complete list of the species collected is available by request from the corresponding author.

We found no difference in the number of piscivorous species captured in hypoxic and normoxic environments $\left(\chi^{2}=0.23 ; \mathrm{p}=0.63 ; \mathrm{df}=1\right.$; Figure 2$)$. However, we captured more piscivorous fish at the normoxic than at the hypoxic sampling points $\left(\chi^{2}=104.40 ; \mathrm{p}<0.001\right.$; $\mathrm{df}=1$; Table 1).

\section{Discussion}

The concentration of dissolved oxygen is an important factor that influences the spatial distribution 


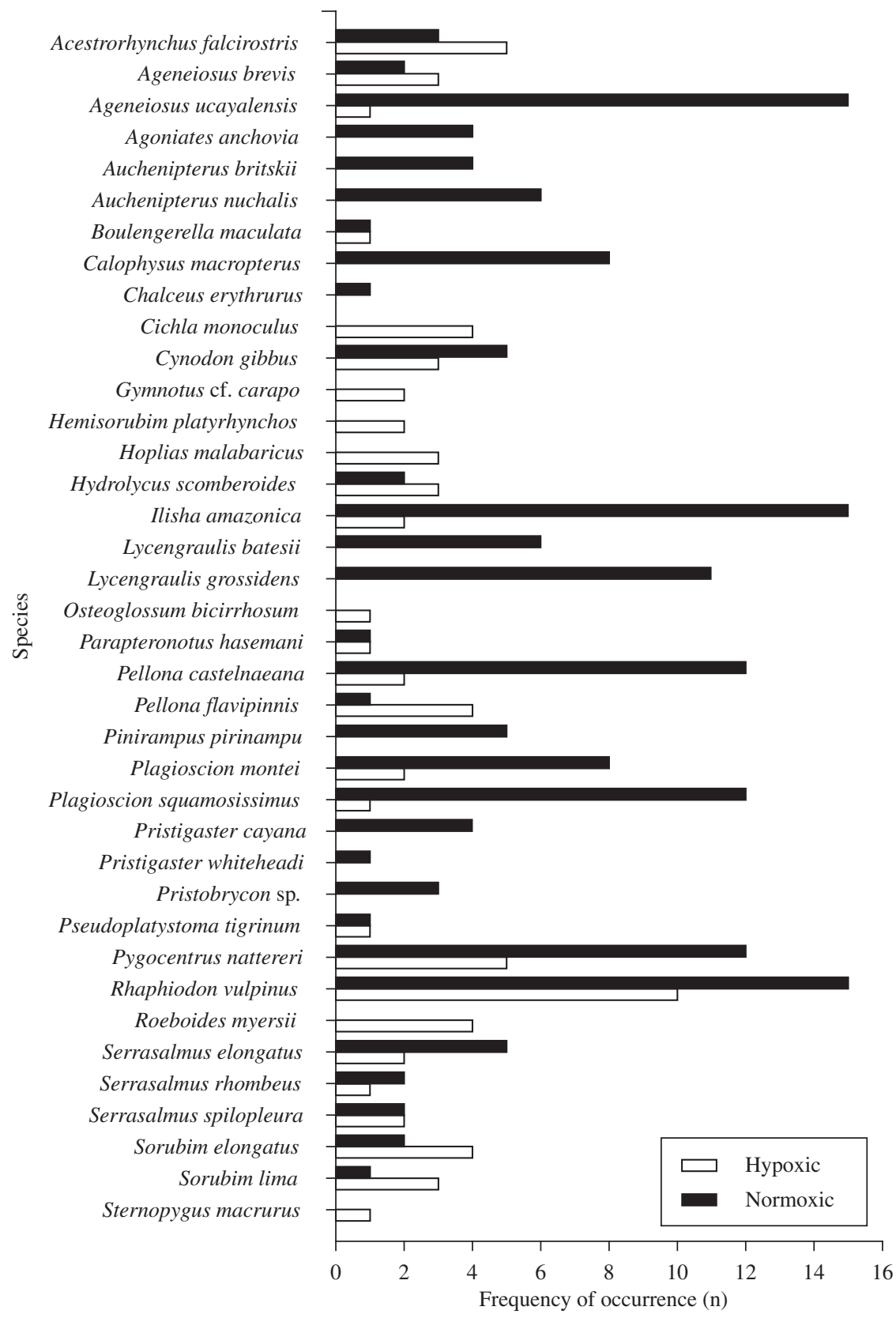

Figure 2. Frequency of occurrence of piscivorous fish species collected in hypoxic and normoxic conditions in the Catalão area during May-June of 2003 and June of 2004. Species are shown in alphabetical order.

of fish and their interactions (Kramer, 1987; Chapman et al., 1995; McKinsey and Chapman, 1998). In the Catalão floodplain, the distribution of piscivorous fish was related to the dissolved oxygen present in the water. Areas with low dissolved oxygen concentrations had fewer piscivorous fish when compared to normoxic areas. These hypoxic areas seem to be serving as refuges for prey species, in function of a supposed lower frequency of predator-prey encounter rate. Chapman et al. (1995; 1996a; 1996b) found that native fish in Lake
Victoria use swampy, hypoxic areas along the margin as refuges against predation by Nile perch (Lates niloticus (Linnaeus, 1758), Perciformes: Latidae), an introduced species that has little tolerance for low dissolved oxygen concentrations. Despite the ability of many Amazonian species to tolerate low dissolved oxygen concentrations (Saint-Paul, 1984; Saint-Paul and Soares, 1987; AlmeidaVal and Hochachka, 1995; Val and Almeida-Val, 1995; Soares and Junk, 2000; Chiparri-Gomes et al., 2003), the relatively low density of piscivorous fish in our hypoxic 
Table 1. Piscivorous and non-piscivorous fishes (\%) collected in hypoxic and normoxic conditions in the Catalão area during May-June of 2003 and June of 2004.

\begin{tabular}{crccc}
\hline \multirow{2}{*}{ Sample } & \multicolumn{2}{c}{ Hypoxic } & \multicolumn{2}{c}{ Normoxic } \\
\cline { 2 - 5 } & Piscivorous & Non-piscivorous & Piscivorous & Non-piscivorous \\
\hline 1 & $8(7.1)$ & $104(92.5)$ & $22(47.9)$ & $16(42.1)$ \\
2 & $14(15.2)$ & $78(84.8)$ & $27(32.9)$ & $55(67.1)$ \\
3 & $7(14.9)$ & $40(85.1)$ & $16(35.6)$ & $29(64.4)$ \\
4 & $5(12.2)$ & $36(87.8)$ & $16(32.6)$ & $33(67.4)$ \\
5 & $13(23.6)$ & $42(76.4)$ & $12(36.4)$ & $21(63.6)$ \\
6 & $8(6.7)$ & $112(93.3)$ & $28(48.3)$ & $30(51.7)$ \\
7 & $8(16.3)$ & $41(83.7)$ & $2(40.0)$ & $3(60.0)$ \\
8 & $2(4.8)$ & $40(95.2)$ & $17(37.0)$ & $29(63.0)$ \\
9 & $0(0)$ & $10(100)$ & $21(23.3)$ & $69(76.7)$ \\
10 & $8(6.6)$ & $114(93.4)$ & $9(23.7)$ & $29(76.3)$ \\
\hline
\end{tabular}

sampling sites suggests that, in the Catalão area, piscivorous species may be less tolerant to low oxygen conditions than the fish community at large.

Low dissolved oxygen availability exerts a strong evolutionary selective pressure for a variety of morphological, physiological, and behavioral adaptations that allow survival in hypoxic conditions. Morphological adaptations include the expansion of gill surface area and the presence of specialized organs for aerial respiration, whereas behavioral and physiological adaptations include lower levels of activity, changes in respiration rate, an increased use of the water-air interface, lower metabolic rates, and variations in the hemoglobin concentration in the blood (e.g., Hochachka, 1982; Kramer, 1987; Graham, 1997; Chapman et al., 2002). Of the seven species found exclusively at our hypoxic sampling sites, five are known to have mechanisms that allow survival in hypoxic environments: Cichla monoculus Spix and Agassiz, 1831 (enzymatic adjustmens) (Almeida-Val et al., 1995), Gymnotus carapo Linnaeus, 1758 (facultative aerial respiration using the modified swim bladder) (Liem et al., 1984), Hoplias malabaricus (Bloch, 1794) (anaerobic metabolism and aquatic surface respiration) (Driedzic et al., 1978; Soares, 1993), Osteoglossum bicirrhosum (Cuvier, 1829) (aquatic surface respiration) (Soares, 1993) and Sternopygus macrurus (Bloch and Schneider, 1801) (aquatic surface respiration) (Crampton, 1998). At present, we are unable to understand the precise influence that hypoxic environments have on fish distribution in várzea floodplains. Further behavioral studies are necessary to understand how factors such as surface-breathing habits may allow piscivorous species to occupy these environments.

The ability to withstand low oxygen concentrations seems to be important in order to occupy habitats with lower predation pressure in the floodplains. Nevertheless, the structural complexity of aquatic environments may also influence the predation pressure to which prey species are exposed. Although we did not quantitatively measure the structural complexity of our sampling sites, we believe that flooded forests (hypoxic sampling sites) are structurally more complex than open-water areas (normoxic sampling sites). Prey species are known to move to areas with more complex habitat structure where predator efficiency (especially that of visually guided predators) may be lower (Werner et al., 1983; Mittelbach, 1986; Brown and Moyle, 1991). Additionally, the sampling gear used in the present study may have underestimated the abundance of certain types of predatory fish, since gill-net capture rates are dependent on the movement of fish through a given area. Thus, we probably captured fewer "sit-and-wait" predators than that actively pursue their prey. Nevertheless, there is no reason to believe that such sampling bias have affected differently our catches in open areas or in the flooded forest.

Junk et al. (1983) found a high proportion of juvenile fish inhabiting hypoxic environments in Lake Camaleão, a floodplain area close to the Catalão. While we cannot confirm this fact in our sampling sites (the mesh-size of our nets precluded the capture of many juveniles), we believe that hypoxic environments in várzea, especially floating macrophytes stands, are important for the protection of juvenile fish (Araújo-Lima et al., 1986; Sánchez-Botero and Araújo-Lima, 2001), which further contribute to improve the survival rate of non-predatory species.

Acknowledgments - This study was developed during the field course "Dinâmica de áreas alagáveis" of the INPA/UFAM postgraduation program. The authors are indebted to Luiz C. F. da Silva for the help during the fieldwork, and to the Conselho Nacional de Desenvolvimento Científico e Tecnológico (CNPq) for Master's Degree grants for M.B. Anjos and R.R. de Oliveira; to C. P. de Deus for a critical review of an earlier version of this manuscript; and to BADPI/INPA for logistical and financial support.

\section{References}

ALMEIDA-VAL, VMF. and HOCHACHKA, PW., 1995. Airbreathing fishes: metabolic biochemistry of the first diving 
vertebrates, p. 45-55. In HOCHACHKA, PW. and MOMMSEN, T. (eds.), Biochemistry and molecular biology of fishes, Elsevier Science, Amsterdan, $468 \mathrm{p}$.

ALMEIDA-VAL, VMF., FARIAS, IP., SILVA, MNP., DUNCAN, WP. and VAL, AL., 1995. Biochemical adjustments to hypoxia by Amazon cichlids. Braz. J. Med. Biol. Res., vol. 28, no. $11-12$, p. $1257-1263$.

ARAÚJO-LIMA, CARM., PORTUGAL, LPS. and FERREIRA, EG., 1986. Fish-macrophyte relationship in the Anavilhanas Archipelago, a black water system in the Central Amazon. $J$. Fish. Biol., vol. 29, no. 1, p. 1-11.

BROWN, LR. and MOYLE, PB., 1991. Changes in habitat and microhabitat partitioning within an assemblage of stream fishes in response to predation by Sacramento squawfish (Ptychocheilus grandis). Can. J. Fish. Aquat. Sci., vol. 48, no. 5, p. 849-856.

CHAPMAN, LJ., KAUFMAN, LS., CHAPMAN, CA., and MCKENZIE, FE., 1995. Hypoxia tolerance in twelve species of east African cichlids: potencial for low oxygen refugia in Lake Victoria. Conservation Biology, vol. 9, no. 5, p. 1274-1287.

CHAPMAN, LJ., CHAPMAN, CA. and CHANDLER, M., 1996a. Wetland ecotones as refugia for endangered fishes. Biological Conservation, vol. 78, no. 3, p. 263-270.

CHAPMAN, LJ., CHAPMAN, CA., OGUTU-OHWAYO, R., CHANDLER, M., KAUFMAN, L. and KEITER, AE., 1996b. Refugia for endangered fishes from an introduced predator in Lake Nabugabo, Uganda. Conservation Biology, vol. 10, no. 2, p. 554-561.

CHAPMAN, LJ., CHAPMAN, CA., NORDLIE, FG. and ROSENBERGER, AE., 2002. Physiological refugia: swamps, hypoxia tolerance and maintenance of fish diversity in the Lake Victoria region. Comp. Biochem. Physiol., vol. 133, no. 3, p. 421-437.

CHIPARRI-GOMES, AR., LOPES, NP., PAULA-SILVA, MN., OLIVEIRA, AR. and ALMEIDA-VAL, VMF., 2003. Hypoxia tolerance and adaptations in fishes: the case of Amazon cichlids, p. 37-54. In VAL, AL. and KAPOOR, BG. (eds.), Fish adaptations, Science Publishers, New Hampshire, 432 p.

CRAMPTON, WGR., 1998. Effects of anoxia on the distribution, respiratory strategies and electric signal diversity of gymnotiform fishes. J. Fish. Biol., vol. 53, suppl. a, p. 307-330.

DOVALE, JD., 2003. Composição, diversidade e abundância da ictiofauna na área do Catalão, Amazônia Central. Unpublished M. Sc. Thesis, UFAM-INPA, Manaus, 66 p.

DRIEDZIC, WR., PHLEGER, CF., FIELDS, JHA. and FRENCH, C., 1978. Alterations in energy metabolism associated with the transition from water to air breathing in fish. Can. J. Zool., vol. 56, no. 4, p. 730-735.

FERREIRA, EJG., ZUANON, JAS. and SANTOS, GM., 1998. Peixes Comerciais do Médio Amazonas: Região de Santarém, Pará. IBAMA, Brasília, 211 p.

FURCH, K. and JUNK, WJ., 1997. Physicochemical conditions in floodplains, p. 69-108. In JUNK, WJ. (ed.), The Central Amazon Floodplain: Ecology of a pulsing system, Springer Verlag, New York, $525 \mathrm{p}$.

GOULDING, M., 1980. The Fishes and the forest: exploration in Amazonian natural history. University of California Press, California, $280 \mathrm{p}$.
GRAHAM, JB., 1997. Air-breathing fishes. Academic Press, San Diego, 299 p.

HOCHACHKA, PW., 1982. Anaerobic metabolism: living without oxygen, p. 138-150. In TAYLOR, CR., JOHANSEN, $\mathrm{K}$. and BOLIS, L. (eds.), A companion to animal physiology, University of Cambridge Press, Cambridge, 365 p.

JUNK, WJ., 1980. Áreas inundáveis - um desafio para a limnologia. Acta Amazonica, vol. 10, no. 4, p. 775-795.

JUNK, WJ., SOARES, GM. and CARVALHO, FM., 1983. Distribution of fish species in a lake of the Amazon river floodplain near Manaus (Lago Camaleão), with special reference to extreme oxygen conditions. Amazoniana, vol. 7, no. 4 , p. 397-431.

KRAMER, DL., 1987. Dissolved oxygen and fish behavior. Env. Biol. Fish., vol. 18, no. 2, p. 81-92.

KRAMER, DL., LINDSEY, CC., MOODIE, GEE. and STEVENS, ED., 1978. The fishes and the aquatic environment of the central Amazon basin, with particular reference to respiratory patterns. Can. J. Zool., vol. 56, no. 4, p. 717-729.

KRAMER, DL., MANLEY, D. and BOURGEOIS, R., 1983. The effect of respiratory mode and oxygen concentration on the risk of aerial predation in fishes. Can. J. Zool., vol. 61, no. 3, p. 653-665.

LIEM, KF., ECLANCHER, B. and FINK, WL., 1984. Aerial respiration in the banded knife fish Gymnotus carapo (Teleostei: Gymnotoidei). Physiol. Zool., vol. 57, no. 1, p. 185-195.

MCKINSEY, DM. and CHAPMAN, LJ., 1998. Dissolved oxygen and fish distribution in a Florida spring. Env. Biol. Fish., vol. 53, no. 2, p. 211-223.

MELACK, JM. and FISHER, TR., 1983. Diel oxygen variations and their ecological implications in Amazon floodplain lakes. Arch. Hydrobiol., vol. 98, no. 4, p. 422-442.

MITTELBACH, G., 1986. Predator-mediated habitat use: some consequences for species interactions. Env. Biol. Fish., vol. 16, no. 1-3, p. 159-169.

REIS, RE., KULLANDER, SO. and FERRARIS-JR., CJ., 2003. Check list of the freshwater fishes of South and Central America. Edipucrs, Porto Alegre, 742 p.

ROBERTS, TR., 1972. Ecology of fishes in the Amazon and Congo basins. Bull. Mus. Comp. Zool., vol. 143, no. 2, p. 117-147.

SAINT-PAUL, U., 1984. Physiological adaptation to hypoxia of a neotropical characoid fish Colossoma macropomum, Serrasalmidae. Env. Biol. Fish., vol. 11, no. 1, p. 53-62.

SAINT-PAUL, U. and SOARES, MGM., 1987. Diurnal distribution and behavioral responses of fishes to extreme hypoxia in an Amazon floodplain lake. Env. Biol. Fish., vol. 20, no. 2, p. 91-104.

SÁNCHEZ-BOTERO, JI. and ARAÚJO-LIMA, CARM., 2001. As macrófitas aquáticas como berçário para a ictiofauna de várzea do rio Amazonas. Acta Amazonica, vol. 31, no. 3, p. 437-447.

SANTOS, GM. and FERREIRA, EJG., 1999. Peixes da Bacia Amazônica, p. 345-373. In LOWE-MCCONNELL, RH. (ed.), Estudos Ecológicos de Comunidades de Peixes Tropicais, EDUSP, São Paulo, 534 p. 
SCHMIDT, GW., 1973. Primary production of phytoplankton in the tree types of Amazonian waters. II. The limnology of a tropical flood-plain lake in the Central Amazonia (Lago do Castanho). Amazoniana, vol. 4, no. 2, p. 139-203.

SOARES, MGM., 1993. Estratégias respiratórias em peixes do Lago Camaleão (Ilha Marachantaria), AM, Brasil. Unpublished Ph.D. Dissertation, INPA-UFAM, Manaus, 183 p.

SOARES, MGM. and JUNK, WJ., 2000. Respiratory adaptations of five curimatids species (Teleostei, Curimatidae) to oxygen depletion in an Amazonian Floodplain lake. Verh. Internat. Verein. Limnol., vol. 27, no. 2, p. 1063-1069.
SOARES, MGM., ALMEIDA, RG. and JUNK, WJ., 1986. The trophic status of the fish fauna in Lago Camaleão, a macrophyte dominated floodplain lake in the middle Amazon. Amazoniana, vol. 9 , no. 4 , p. 511-526.

VAL, AL. and ALMEIDA-VAL, VMF., 1995. Fishes of the Amazon and their environment: physiological and biochemical features. Springer-Verlag, Heidelberg, $224 \mathrm{p}$.

WERNER, EE., GILLIAM, JF., HALL, DJ. and MITTELBACH, GG., 1983. An experimental test of the effects of predation risk on habitat use in fish. Ecology, vol. 64, no. 6, p. 1540-1548.

ZAR, JH., 1996. Biostatistical analysis. Prentice-Hal, New Jersey, $4^{\text {th }}$ edition, $663 \mathrm{p}$. 